\title{
Reinventing the Brooklyn Navy Yard: a national model for sustainable urban industrial job creation
}

\author{
A. H. Kimball \& D. Romano \\ Brooklyn Navy Yard Development Corporation, USA
}

\begin{abstract}
When the federal government decommissioned the nation's foremost naval shipbuilding facility in 1966, it was a devastating blow to Brooklyn's economy. Tens of thousands of jobs were lost and the rusting, dilapidated Yard came to symbolize the massive loss of urban manufacturing jobs in New York and across the United States. Acquired by the City of New York in 1969, Yard management struggled to rekindle large-scale manufacturing and the days of the smoke stacks. It wasn't until the late-1980s, under the leadership of new management, Brooklyn Navy Yard Development Corporation (BNYDC), that the Yard began to turn the corner, emerging from near bankruptcy by focusing on a new kind of tenant. Very small, often creative class-driven, light industrial businesses with long-term relevance to New York City's economy began to populate Yard buildings. Today the Navy Yard is widely recognized as a national model for the creation of well-paying urban industrial jobs. Having doubled its employment in the last ten years, the Yard is now home to more than 275 local businesses and 6,000 people who work in a variety of industries from traditional maritime to media, medicine, high-end craft, and green manufacturing. Over the next two years, BNYDC will add nearly two million square feet of new space and 2,000 new jobs. Investments in cutting-edge green infrastructure have nurtured a rapidly growing cluster of green manufacturers, lowered the Yard's carbon footprint and made it a better neighbor to surrounding communities. How has the Yard's growth continued unabated through the nation's worst recession since the 1930s? Practical lessons learned from this naval base reuse can serve broadly as
\end{abstract}


a case study for urban areas that need to reinvent and are ready to embrace a new industrial economy.

Keywords: economic development, industrial retention, infrastructure, adaptive reuse, sustainability, manufacturing, employment, military facilities, base realignment.

\section{Historical background}

The 300-acre Brooklyn Navy Yard sits on Wallabout Bay between the Manhattan and Williamsburg Bridges on the East River across from Manhattan. For 165 years, the Brooklyn Navy Yard produced America's mightiest warships, including the Maine, the Missouri, and the Arizona, and related technologies that helped shape the nation's future. The closing of the Yard in 1966 was the bruising culmination of the Navy's steady post-WWII drawdown. It took decades for the Yard, and its neighbors, to recover. The largest closure of any military facility up to that point in U.S. history became a symbol of government disinvestment, the decline of large-scale manufacturing, and urban decay.

After the federal government closed the Yard, the largest portions of its 300acre site - with complex and extensive subsurface utilities and infrastructure, as well as its massive dry docks and buildings - was sold to the City of New York for \$23.5 million in 1969 for reuse as an industrial park [1].

\subsection{Looking for the "Big Fix"}

After closure, early Yard management focused on the "Big Fix", seeking a small number of large manufacturers to replace the thousands of lost jobs related to naval ship production. These efforts included trying to bring an automobile plant and steel mill to the Yard. Such "Big Fix" efforts ran counter to overall national trends for large manufacturers producing standardized commodity products to move production to low-cost areas around the globe and none of these efforts proved successful. Only large-scale private maritime shipbuilding and repair enjoyed any success. However, that industry was in decline in New York and could not survive without significant subsidy or long-term assurance of government work.

In the mid-1980s, closure of the two major maritime tenants with associated loss of 8,000 jobs, forced BNYDC management to consider new strategies.

\subsection{Finding the right leasing model}

At its nadir in 1985, the Yard had fewer than 30 businesses, 1000 workers and millions of vacant square feet of space. New management decided to diversify the Yard's tenant base by focusing on small industrial businesses with few other real estate options.

For decades, small industrial businesses in New York City often found it challenging to find stable affordable space. Under New York City's zoning laws, manufacturers often have to compete with retail or commercial businesses for space. Even if they were able to afford the higher rents required for these spaces, 
commercial and retail landlords were often wary of noise, smells and truck traffic generated by industrial businesses. Yard management began focusing on attracting these businesses by cutting up larger spaces once used by private ship builders into small units.

The strategy worked. By the late 1990s, the Yard's four million square feet of space was almost fully leased, with over 230 businesses employing over 3000 workers. And the Yard has continued to grow. Today, the Brooklyn Navy Yard is home over 275 businesses and 6,000 workers in diverse industries that support economic sectors with long-term viability in New York City [2].

Twenty-first Century manufacturing at the Yard includes building sets for film shoots and installations for cultural institutions. It includes restoring artwork. Yard tenants use high-end design and high-technology manufacturing equipment to fabricate products from furniture for luxury apartments to body armor for the U.S. and British Special Forces. Maritime ship repair tenants service the Port of New York and medical testing labs service the rapidly growing health sector [3].

With 99\% occupancy for the last ten years, the Yard has a waiting list of 100 businesses eager to locate there. Many are very small $-70 \%$ of Yard tenants use fewer than 5,000 square feet and have five or fewer employees. But 25\% have over 25,000 square feet and 50 employees, and 5\% have over 50,000 square feet and more than 300 employees.

Conventional industrial leasing theory suggests that a landlord receives more for ground floor space with loading dock access than for upper floors. With scores of artisans willing to pay a premium for small upper floor spaces with quality natural light, the Navy Yard has turned this thinking on its head. New Yard buildings all are multi-story.

\subsection{The city takes notice and invests}

Notwithstanding the success of its leasing strategy, at the turn of the century Yard management faced one other massive challenge: rotting infrastructure. Deteriorating sub-surface water, sewer and electric lines and crumbling piers, some of them dating to the American Civil War period, threatened the Yard's long-term viability. Between the end of WWII and the end of the 1990s fewer than $\$ 10$ million of government funds had gone into basic infrastructure.

Under the leadership of Mayor Michael R. Bloomberg, the City of New York has invested over \$200 million in basic infrastructure needs over the last twelve years. Yard management has leveraged these City investments to generate over $\$ 500$ million in private funding for twelve new industrial buildings that over the next two years will create an additional two million square feet of space. Hundreds of millions more have been invested by Yard tenants for equipment and fit-out. Recognizing this track record of success, the State of New York and federal government have also begun to make significant new capital investments in the Yard [4]. 


\section{Key reasons for continued growth}

While the new leasing strategy targeting very small industrial businesses with long-term economic relevance to the City, and the huge commitment of public investments in basic infrastructure, have been key to the remarkable resurgence of the Brooklyn Navy Yard, these two reasons alone cannot account for the Yard's continued growth, particularly through the Great Recession.

\section{1 "Hassle-free" environment}

As a walled-off industrial park with $24 / 7$ security, the Yard provides a hasslefree environment for its tenants. Industrial businesses enjoy the unique opportunity to load and unload at all hours without disturbing their residential neighbours. Trucks can park overnight and don't have to worry about receiving parking violations.

Since the Yard is a dedicated industrial park, tenants can invest in their premises, knowing that hey will not face eviction from a future rezoning.

\subsection{Governance and management}

BNYDC is a mission-driven not-for-profit that manages the 300 -acre Yard under long-term contract with its owner, the City of New York. Its Board consists of community leaders and business leaders with banking and real estate experience as well as experience within relevant Yard sectors such as entertainment and media as well as. The accumulated wisdom and experience of this Board cannot be overstated.

The Yard's mission requires management to balance securing the highest possible rents with creating the most jobs. Management has responded by populating the Yard with a highly diverse set of tenants. Some are large job creators; some are in industries that are accustomed to paying high rents.

BNYDC's agreement with the City allows management to reinvest its profits back into the Yard rather than simply being turned over to the City as rent. The City allows BNYDC to leverage its rent-roll to fund the construction of new buildings. In addition, BNYDC's ability to provide long-term leases has allowed its tenants to finance large-scale expansion projects.

While it is very difficult to secure financing for industrial projects, particularly in urban areas, with the support of its Board and the City, BNYDC has leveraged available tax credit programs and innovative financing sources, including:

- The federal EB-5 program that allows foreign nationals to invest $\$ 500,000$ into projects in high unemployment communities in exchange for expedited access to permanent resident status.

- The State and federal historic tax credit program that helps facilitate investment in structures built before 1945. The program's criteria meet the vast majority of the Navy Yard's buildings and its goals match BNYDC's commitment to historic preservation. 
- The federal earned income tax credit program that facilitates financing in projects that create significant numbers of well-paying jobs in lowincome communities.

\subsection{Development strategy}

Yard management within the last decade has undertaken significant initiatives to guide the Yard's continued development and industrial growth. Environmental sustainability, historic preservation, improved community presence and access, and tenant promotion together build an attractive identity for the site. Job creation and university partnerships cultivate entrepreneurship and employment in growing industrial sectors.

\subsubsection{Greening the yard}

To foster the development of green manufacturing, minimize the Navy Yard's carbon footprint, and further improve its community presence, BNYDC has made a major commitment to developing green buildings and sustainable infrastructure. Installations include:

- The city's first building-mounted wind turbines;

- The nation's first wind/solar street lamps;

- New York City's largest roof-mounted urban farm that will not only produce fresh produce and local jobs but divert one million gallons of storm water run-off every year;

- Brooklyn's first solar-powered trash compactors;

- A massive water conservation and storm water run-off reduction project of new water and sewer systems, road network and landscaping; and

- A Yard-wide waste management plan diverts tons of waste from landfills, increases recycling efforts in the Yard and lowers tenant carting/hauling costs, with the ancillary benefit of reducing the number of trash-hauling vehicles clogging the Yard's roads.

These efforts to "green" the Yard build good-neighbor relationships with the surrounding community, and build the good-business position that the Yard is an attractive destination for a growing cluster of green manufacturers. A 2009 survey by the New York Industrial Retention Network identified over 30 green manufacturers in the Yard [5].

\subsubsection{Historic preservation}

The Brooklyn Navy Yard is one of the few former Naval base conversion projects whose buildings have continued to be used for exclusively industrial purpose. Most other US Navy Yards have been converted to a mixture of residential, commercial and retail uses.

Maintaining the historic industrial character of the site has not only been the right thing from an historic preservation and sustainability point of view but also created an ambiance desirable to New York's creative class and $21^{\text {st }}$ century manufacturers. 


\subsubsection{Improved community presence and public access}

As recently as 2001, the walls of the Navy Yard were covered with barbed wire. A lack of signage and years of deferred maintenance resulted in a forbidding, often garbage strewn exterior community presence. Over the last decade, not only has the barbed wire been removed, but also numerous perimeter improvements have been undertaken, including:

- New signage at all entrances including historic and modern manufacturing photos with the slogan "We Used to Launch Ships, Now We Launch Businesses";

- Creation of the Brooklyn Waterfront Greenway, a bike and pedestrian path with attractive landscaping;

- Plans for a six-acre redevelopment of a site filled with deteriorated houses from the 1850 s called Admirals Row that will result in nearly 250,000 square feet of industrial and retail space with over 500 permanent local jobs, along with significant historic preservation ; and

- Plans for a two-acre memorial park on the site of a former Yard cemetery.

The most important of the community outreach efforts was completed in November 2011, when BNYDC opened a unique exhibition, visitor and employment center, Brooklyn Navy Yard Center at BLDG 92. The public has been allowed behind the walls on a daily basis for the first time since 1801 to experience an exhibit celebrating the Yard's, past, present and future, including profiles of its unique tenants. BLDG 92 also houses the Yard's Employment Center, which has place 1000 mostly local residents in jobs in the Yard over the last six years. Ten percent of those placements have gone to very low-income residents living in local public housing and $10 \%$ have gone to formerly incarcerated individuals.

\subsection{Tenant promotion and business-to-business activity}

BNYDC promotes Yard tenants publicly and inside the Yard, encouraging business-to-business activity, and helping tenants identify opportunities to pool materials, resources and labor. BNYDC also contracts locally as much as possible on capital and operations projects.

BLDG 92 has become a key element of the Yard's effort to promote its tenants. Seventeen Yard tenants were contracted to complete various portions of the exhibit and building design and construction, an exemplary demonstration of Yard expertise and ability. A community commitment to local sourcing and job creation meant over $20 \%$ of the dollar value in construction went to local contractors, over $40 \%$ to minority- and women-owned businesses and, over $20 \%$ of the workforce came from the surrounding communities.

One of the six galleries in the exhibit is focused solely on the Yard's tenants, their products and the remarkable diversity of their workforce. 


\subsection{Local job creation}

Core to BNYDC's mission is the creation of well-paying local industrial jobs. Of the 6,000 people who come to work at the Navy Yard, 35\% come from the surrounding communities and 50\% are Brooklyn residents. BNYDC has operated an on-site Employment Center for over 10 years, which finds employment opportunities for local residents with a strong focus on placing workers with Yard tenants.

Local job creation and minority and women-owned business construction contracting are key building blocks for BNYDC with the community. Its track record of success in this area has been instrumental in the continued growth of public support for new development in the Yard [6].

\subsection{University partnerships}

Universities and colleges have played a key role in the renaissance of the Navy Yard producing graduates who have become the backbone of the creative class of entrepreneurs who have started manufacturing businesses there [7].

In recent years, more formal partnerships have emerged:

- Pratt University helped start a sustainable design incubator;

- Brooklyn College is establishing the City's first graduate public film school; and.

- Carnegie Mellon is developing a plan for a graduate applied sciences program focused on entertainment and media technology research.

\section{Yard tenant highlights}

The diversity of Yard tenants includes commercial artists, artisans, and woodworkers serving the City's cultural institutions and housing markets; entertainment, film and media anchored by the largest film studios on the East Coast; e-commerce fulfilment; high-end designers combined with on-site manufacturing; maritime ship repair; and warehouse distribution. Across these sectors, a rapidly growing cluster of green manufacturers has emerged.

The Navy Yard's largest employers (number of workers in parenthesis) include:

- Steiner Studios, the largest movie and television studios on the East Coast (1200).

- Cumberland Packing, manufacturers of Sweet 'N Low and Sugar in the Raw (400).

- $\quad$ B\&H Photo \& Electronics, e-commerce distribution (300).

- GMD Marine, ship repair (230).

- Mercedes Distribution, e-commerce fulfilment for companies such as Gilt Groupe and Jack Threads (350).

- $\quad$ Shiel Medical Labs, New York City's largest privately owned lab (600) 
The Brooklyn Navy Yard is home to over 30 green manufacturers including:

- IceStone, the only gold-level cradle-to-cradle surface manufacturer, producing countertops made from recycled glass.

- Duggal, a graphics and displays company on the cutting edge of renewable energy lighting.

- ARES Printing \& Packaging, a pioneer of green packaging and sustainable printing.

- Scott Jordan Furniture, a high-end furniture manufacturer that uses only eco-finishes and locally-sourced and sustainably harvested wood.

\section{Conclusion}

Revitalizing the manufacturing sector has become a core component of US economic policy. Urban manufacturing has a particularly important role to play in this revitalization effort because cities are home to both dense concentrations of small manufacturers and to populations in need of living-wage jobs. Manufacturing jobs typically pay $25-40 \%$ more than service sector jobs, are more likely to provide health benefits, and result in pathways to the middle class. Cities are also often home to decommissioned military installations offering a unique opportunity to further industrial revitalization efforts.

With the strong support of the City of New York, the mission-driven Brooklyn Navy Yard Development Corporation has transformed the Navy Yard over the last decade into a model for the creation of well-paying urban industrial jobs.

As municipalities and policy makers seek to revitalize urban manufacturing, the experience of the Brooklyn Navy Yard is worth study and replication.

\section{References}

[1] Brooklyn Navy Yard Development Corporation Master Lease with the City of New York, 1981.

[2] Jacobs, K., Made in Brooklyn: The borough plays host to a manufacturing revival that combines high tech with a decidedly green sensibility. Metropolis Magazine, 6/2010.

[3] Preliminary Findings: Brooklyn Navy Yard Economic Impact Assessment, Pratt Center for Community Development and Brookings Institution, 2012.

[4] Mistry, N., Byron, J., The Federal Role in Supporting Urban Manufacturing, Pratt Center for Community Development and Brookings Institution, 2011.

[5] Green Business Directory. BNYDC and New York Industrial Retention Network, 2009.

[6] DeFreitas, R., Report on MWBE and Local Workforce Utilization: BLDG 92 Brooklyn Navy Yard Development Corporation, Crescent Consulting, $7 / 2011$.

[7] Heike, M., What is the Role of the University in Creating a HighTechnology Region? Journal of Urban Technology, v. 14, 2007. 